\title{
RETRACTED ARTICLE: Beyond necessity versus opportunity entrepreneurship: some lessons from English deprived urban neighbourhoods
}

\author{
Nick Williams • Colin C. Williams
}

Published online: 15 April 2011

(C) Springer Science+Business Media, LLC 2011

This article, published online in International Entrepreneurship and Management Journal, 10.1007/s11365-011-0186-z, is a duplicate version of another article entitled "Beyond necessity versus opportunity entrepreneurship: some lessons from English deprived urban neighbourhoods" written by the same authors and published in the same journal. Springer apologizes to the readers of the journal for not detecting this duplication during the publishing process.

\footnotetext{
This article, published online in International Entrepreneurship and Management Journal, 10.1007/ s11365-011-0186-z, is a duplicate version of another article entitled "Beyond necessity versus opportunity entrepreneurship: some lessons from English deprived urban neighbourhoods" written by the same authors and published in the same journal. Springer apologizes to the readers of the journal for not detecting this duplication during the publishing process.
}

\section{N. Williams $(\bowtie)$}

Sheffield Business School, Sheffield Hallam University, Howard Street, Sheffield S1 1WB, UK e-mail: nick.williams@shu.ac.uk

C. C. Williams

Management School, University of Sheffield, Sheffield, UK 